\title{
Index to Volume 50
}

\section{A}

Abels, Eileen G. See Agosto, Denise E. ACADEMIC LIBRARIES

Cassidy, Erin Dorris, James Britsch, Glenda Griffin, Tyler

Manolovitz, Lisa Shen, and Linda Turney. Higher Education and Emerging Technologies:

Student Usage, Preferences, and Lessons for Library Services, 50(4):380-391

Duncan, Vicki, and Angie Gerrard. All Together Now! Integrating Virtual Reference in the Academic Library, 50(3):280_ 292

East, John W. "The Rolls Royce of the Library Reference Collection": The Subject Encyclopedia in the Age of Wikipedia, 50(2):162-169

Kooy, Brian K., and Sarah K. Steiner. Protection, Not Barriers: Using Social Software Policies to Guide and Safeguard Students and Employees, 50(1):59-71

Newby, Jill. Entering Unfamiliar Territory: Building an Information Literacy Course for Graduate Students in Interdisciplinary Areas, 50(3):224-229

O'Connor, Lisa, and Kacy Lundstrom. The Impact of Social Marketing Strategies on the Information Seeking Behaviors of College Students, 50(4):351-365

Sobel, Karen, and Kenneth Wolf. Updating Your Tool Belt: Redesigning Assessments of Learning in the Library, 50(3):245-258

Stover, Mark. From Reference Librarian to Interim Dean: A
Journey of Comparisons and Contrasts, 50(4):322-324

Strothmann, Molly, and Karen Antell. The Live-In Librarian: Developing Library Outreach to University Residence Halls, 50(1):48-58

Wolfe, Judith A., Ted Naylor, and Jeanetta Drueke. The Role of the Academic Reference Librarian in the Learning Commons, 50(2):108-113

Wong, Gabrielle K.W. Facilitating Students' Intellectual Growth in Information Literacy Teaching, 50(2):114-118

Accidental Technologist (column) Hensley, Merinda Kaye. Citation Management Software: Features and Futures, 50(3):204-208

The Alert Collector (column)

Baker, Jen, John Charles, Mary K. Chelton, Sarah Statz Cords, Lisa Fraser, Gwen Glazer, Neil Hollands, Teresa L. (Terry) Jacobsen, Cindy Orr, Joyce Saricks, Jacqueline Sasaki, Katie Mediatore Stover, Barry Trott, Kimberly Wells, and David Wright. A Selection of Core Resources for Readers' Advisory Service, 50(1):6, 8-12

Bivens-Tatum, Wayne. The Compleat Philosophy Librarian, 50(4):315-318

Collins, Kathleen. New-Wave Knitting: 38 Resources for a Core Collection, 50(3):210-215

All Together Now! Integrating Virtual Reference in the Academic Library, 50(3):280292

Announcing the Move of Reference $\mathcal{E}$ User Services Quarterly (RUSQ) to an Online Publication, 50(4):314
Antell, Karen. See also Strothmann, Molly

Antell, Karen, ed. Professional Materials, 50(1):8791, 50(2):191-196, 50(3):305308, 50(4):404-408

"Are We Getting Warmer?" Query Clarification in Live Chat Virtual Reference, 50(3):259-279

B

Baker, Jen. John Charles, Mary K. Chelton, Sarah Statz Cords, Lisa Fraser, Gwen Glazer, Neil Hollands, Teresa L. (Terry) Jacobsen, Cindy Orr, Joyce Saricks, Jacqueline Sasaki, Katie Mediatore Stover, Barry Trott, Kimberly Wells, and David Wright

A Selection of Core Resources for Readers' Advisory Service, 50(1):6, 8-12

Barton, Jessica L. See Taylor, Stephanie D.

Bejune, Matthew M., and Sara E. Morris

The Development of the Virtual Notebook, a Wiki-Based Ready Reference Technology, 50(1):27-34

Best Free Web Reference Websites, 50(1):19-24

Best Historical Materials, 50(1):2526

Best of the Best Business Websites, 50(2):132-134

BIBLIOGRAPHIC INSTRUCTION

Sobel, Karen, and Kenneth Wolf. Updating Your Tool Belt: Redesigning Assessments of Learning in the Library, 50(3):245-258

BIBLIOGRAPHIES

Guidelines for the Preparation of a Bibliography, 50(1):99-101 


\section{INDEX TO VOLUME 50}

Bivens-Tatum, Wayne

The Compleat Philosophy Librarian, 50(4):315-318

A Blueprint for Building Online Reference Knowledge Bases, 50(2):152-161

Bosančić, Boris

A Blueprint for Building Online Reference Knowledge Bases, 50(2):152-161

Britsch, James. See Cassidy, Erin Dorris

BUSINESS REFERENCE SOURCES

BRASS Business Reference Sources

Committee. Outstanding

Business Reference Sources, 50(2):126-130

Business Reference and Services Section Education Committee. Best of the Best Business Websites, 50(2):132-134

\section{C}

Cassidy, Erin Dorris, James Britsch, Glenda Griffin, Tyler Manolovitz, Lisa Shen, and Linda Turney Higher Education and Emerging Technologies: Student Usage, Preferences, and Lessons for Library Services, 50(4):380-391

CATALOGING

Miller, Liz. Resource Description and Access (RDA): An Introduction for Reference Librarians, 50(3):216-222

Catching On: Management Training in Depository Libraries, 50(2):119-121

Charles, John. See Baker, Jen CHAT REFERENCE SERVICES

Radford, Marie L., Lynn Silipigni Connaway, Patrick A. Confer, Susanna Sabolcsi-Boros, and Hannah Kwon. "Are We Getting Warmer?" Query Clarification in Live Chat Virtual Reference, 50(3):259-279

Chelton, Mary K. See Baker, Jen

Citation Management Software: Features and Futures, 50(3):204208

Clean, Green, and Not So Mean: Can Business Save the World? 50(2):135-140

\section{COLLECTION DEVELOPMENT \\ Guidelines for Liaison Work in Managing Collections and Services, 50(1):97-98}

Collins, Kathleen

New-Wave Knitting: 38 Resources for a Core Collection, 50(3):210-215

The Compleat Philosophy Librarian, 50(4):315-318

Confer, Patrick A. See Radford, Marie L.

CONFERENCES

BRASS Program Planning Committee. Clean, Green, and Not So Mean: Can Business Save the World?, 50(2):135-140

Connaway, Lynn Silipigni. See Radford, Marie L.

Cords, Sarah Statz. See Baker, Jen

\section{DATABASES}

Bosančić, Boris. A Blueprint for Building Online Reference Knowledge Bases, 50(2):152161

\section{DEPOSITORY LIBRARIES}

Ryan, Marianne. Catching On: Management Training in Depository Libraries, 50(2):119-121

The Development of the Virtual Notebook, a Wiki-Based Ready Reference Technology, 50(1):2734

DIGITAL REFERENCE SERVICES. See VIRTUAL REFERENCE SERVICES

DISASTER PLANNING

Guidelines for Resource-Sharing Response to Natural and ManMade Disasters, 50(2):197-198

Dixon, Lydia, Cheri Duncan, Jody Condit Fagan, Meris Mandernach, and Stefanie E.Warlick

Finding Articles and Journals via Google Scholar, Journal Portals, and Link Resolvers: Usability Study Results, 50(2):170-181

Drueke, Jeanetta. See Wolfe, Judith A.

Duncan, Cheri. See Dixon, Lydia Duncan, Vicki, and Angie Gerrard
All Together Now! Integrating

Virtual Reference in the Academic Library, 50(3):280-292

Dunneback, Katie

E-Books and Readers' Advisory, 50(4):325-329

\section{E}

East, John W.

"The Rolls Royce of the Library Reference Collection": The Subject Encyclopedia in the Age of Wikipedia, 50(2):162-169

E-Books and Readers' Advisory, 50(4):325-329

Elmborg, James K.

Libraries as the Spaces Between Us: Recognizing and Valuing the Third Space, 50(4):338-350

ENCYLOPEDIAS

East, John W. "The Rolls Royce of the Library Reference Collection": The Subject Encyclopedia in the Age of Wikipedia, 50(2):162-169

Entering Unfamiliar Territory: Building an Information Literacy Course for Graduate Students in Interdisciplinary Areas, 50(3):224-229

\section{$\mathbf{F}$}

Fagan, Judy Condit. See Dixon, Lydia

Farewell Stacks . . Hello Digital, 50(4):312-313

Ferrell, Shelley

Who Says There's a Problem? A New Way to Approach the Issue of "Problem Patrons," 50(2):141-151

Finding Articles and Journals via Google Scholar, Journal Portals, and Link Resolvers: Usability Study Results, 50(2):170-181

A Follow-Up Study of the Factors Shaping the Career Choices of Library School Students at the University of Alabama, 50(1):3547

Food and Travel: Twin Readers' Advisory Pleasures, 50(2):122125

For Your Enrichment (column) Miller, Liz. Resource Description and Access (RDA): An 
Introduction for Reference

Librarians, 50(3):216-222

Perry, Maureen. A Reference

Librarian in Special Collections:

Making the Most of a Learning

Opportunity, 50(4):319-321

Wolfe, Judith A., Ted Naylor, and

Jeanetta Drueke. The Role of the Academic Reference Librarian in the Learning Commons, 50(2):108-113

Fraser, Lisa. See Baker, Jen

From Committees of RUSA

BRASS Business Reference Sources

Committee. Outstanding

Business Reference Sources,

50(2):126-130

BRASS Program Planning

Committee. Clean, Green, and

Not So Mean: Can Business Save

the World?, 50(2):135-140

Business Reference and Services

Section Education Committee.

Best of the Best Business

Websites, 50(2):132-133

Notable Books Council. Notable

Books, 50(4):330-332

RUSA CODES Reading List

Council. The Reading List 2011 , 50(4):335-336

RUSA CODES Reference Sources

Committee. Outstanding

Reference Sources, 50(4):333-

334

RUSA History Section Historical

Materials Committee. Best

Historical Materials, 50(1):25-

26

RUSA Machine-Assisted Reference

Section. Best Free Web

Reference Websites, 50(1):19_

24

From Reference Librarian to Interim

Dean: A Journey of Comparisons

and Contrasts, 50(4):322-324

From the Editor (column)

Farewell Stacks . . Hello Digital, 50(4):312-313

Happy Anniversary, RUSQ, 50(1):4

From the President of RUSA

(column)

Announcing the Move of

Reference \& User Services

Quarterly (RUSQ) to an Online

Publication, 50(4):314

\section{G}

Gerrard, Angie. See Duncan, Vicki

Glazer, Gwen. See Baker, Jen

GOOGLE

Dixon, Lydia, Cheri Duncan, Jody Condit Fagan, Meris Mandernach, and Stefanie E.Warlick. Finding Articles and Journals via Google Scholar, Journal Portals, and Link Resolvers: Usability Study Results, 50(2):170-181

GOVERNMENT DOCUMENTS

Ryan, Marianne. Catching On: Management Training in Depository Libraries, 50(2):119-121

Griffin, Glenda. See Cassidy, Erin Dorris

GUIDELINES

Guidelines for Implementing and Maintaining Virtual Reference Services, 50(1):92-96

Guidelines for Liaison Work in Managing Collections and Services, 50(1):97-98

Guidelines for Resource-Sharing Response to Natural and ManMade Disasters, 50(2):197-198

Guidelines for the Preparation of a Bibliography, 50(1):99-101

\section{H}

Helen E. Haines: A Life with Books, 50(1):14-17

Hensley, Merinda Kaye

Citation Management Software: Features and Futures, 50(3):204-208

Higher Education and Emerging Technologies: Student Usage, Preferences, and Lessons for Library Services, 50(4):380-391

Hollands, Neil. See Baker, Jen

Hooper, Brad

Food and Travel: Twin Readers' Advisory Pleasures, 50(2): 122-125

\section{I}

Identifying Reusable Resources in Digital Reference Responses, 50(4):366-378

The Impact of Social Marketing Strategies on the Information Seeking Behaviors of College Students, 50(4):351-365
Information Literacy and

Instruction (column)

Newby, Jill. Entering Unfamiliar Territory: Building an Information Literacy Course for Graduate Students in Interdisciplinary Areas, 50(3):224-229

Wong, Gabrielle K.W. Facilitating Students' Intellectual Growth in Information Literacy Teaching, 50(2):114-118

INFORMATION SERVICES. See REFERENCE SERVICES

Instructions to Authors, 50(1):102104

Jacobsen, Teresa L. (Terry). See

Baker, Jen

\section{K}

Kern, M. Kathleen, ed.

Accidental Technologist (column), 50(3):204-208

KNITTING

Collins, Kathleen. New-Wave Knitting: 38 Resources for a Core Collection, 50(3):210-215

KNOWLEDGE BASES

Bosančić, Boris. A Blueprint for Building Online Reference Knowledge Bases, 50(2):152161

Kooy, Brian K., and Sarah K. Steiner Protection, Not Barriers: Using Social Software Policies to Guide and Safeguard Students and Employees, 50(1):59-71

Kwon, Hannah. See Radford, Marie L.

L

Libraries as the Spaces Between Us: Recognizing and Valuing the Third Space, 50(4):338-350

LIBRARY INSTRUCTION. See BIBLIOGRAPHIC INSTRUCTION

LIBRARY RESEARCH

Cassidy, Erin Dorris, James Britsch, Glenda Griffin, Tyler Manolovitz, Lisa Shen, and Linda Turney. Higher Education and Emerging Technologies: Student Usage, Preferences, and Lessons for Library Services, 50(4):380-391 


\section{INDEX TO VOLUME 50}

LIBRARY SCIENCE EDUCATION

Agosto, Denise E., Lily Rozaklis, Craig MacDonald, and Eileen G. Abels. A Model of the Reference and Information Service Process: An Educators' Perspective, 50(3):235-244

Taylor, Stephanie D., R. Alexander Perry, Jessica L. Barton, and Brett Spencer. A FollowUp Study of the Factors Shaping the Career Choices of Library School Students at the University of Alabama, 50(1):35-47

LIBRARY SERVICES

Ferrell, Shelley. Who Says There's a Problem? A New Way to Approach the Issue of "Problem Patrons," 50(2):141-151

The Live-In Librarian: Developing Library Outreach to University Residence Halls, 50(1):48-58 Lundstrom, Kacy. See O'Connor, Lisa

\section{M}

MacDonald, Craig. See Agosto, Denise E.

Management (column) Ryan, Marianne. Catching On: Management Training in Depository Libraries, 50(2):119-121

Stover, Mark. From Reference Librarian to Interim Dean: A Journey of Comparisons and Contrasts, 50(4):322-324

Mandernack, Meris. See Dixon, Lydia

Manolovitz, Tyler. See Cassidy, Erin Dorris

Materials Matchmaking: Articulating Whole Library Advisory, 50(3):230-234

Miller, Liz

Resource Description and Access (RDA): An Introduction for Reference Librarians, 50(3):216-222

A Model of the Reference and Information Service Process: An Educators' Perspective, 50(3):235-244

Morris, Sara E. See Bejune, Matthew M.

\section{$\mathbf{N}$}

Naylor, Ted. See Wolfe, Judith A.

Newby, Jill

Entering Unfamiliar Territory: Building an Information Literacy Course for Graduate Students in Interdisciplinary Areas, 50(3):224-229

New-Wave Knitting: 38 Resources for a Core Collection, 50(3):210215

Notable Books, 50(4):330-332

NURSING and PROBLEM

PATIENTS

Ferrell, Shelley. Who Says There's a Problem? A New Way to Approach the Issue of "Problem Patrons," 50(2):141-151

\section{O}

O'Connor, Lisa, and Kacy

Lundstrom

The Impact of Social Marketing Strategies on the Information Seeking Behaviors of College Students, 50(4):351-365

O'Connor, Lisa, ed.

Information Literacy and Instruction (column), 50(2):114-118, 50(3):224-229

ONLINE REFERENCE SOURCES. See VIRTUAL REFERENCE SERVICES

Orr, Cindy. See Baker, Jen

Outstanding Reference Sources, 50(4):333-334

Perry, Maureen

A Reference Librarian in Special Collections: Making the Most of a Learning Opportunity, 50(4):319-321

Perry, R. Alexander. See Taylor, Stephanie D.

Pomerantz, Jeffrey

Identifying Reusable Resources in Digital Reference Responses, 50(4):366-378

PROBLEM PATRONS

Ferrell, Shelley. Who Says There's a Problem? A New Way to Approach the Issue of "Problem Patrons," 50(2):141-151

Protection, Not Barriers: Using Social Software Policies to Guide and Safeguard Students and

Employees, 50(1):59-71

PUBLIC LIBRARIES

Ferrell, Shelley. Who Says There's a Problem? A New Way to Approach the Issue of "Problem Patrons," 50(2):141-151

Williamson, Tara Bannon. Materials Matchmaking: Articulating Whole Library Advisory, 50(3):230-234

\section{$\mathbf{R}$}

Radford, Marie L., Lynn Silipigni Connaway, Patrick A. Confer, Susanna Sabolcsi-Boros, and Hannah Kwon

"Are We Getting Warmer?" Query Clarification in Live Chat Virtual Reference, 50(3):259-279

Readers' Advisory (column)

Dunneback, Katie. E-Books and Readers' Advisory, 50(4):325329

Hooper, Brad. Food and Travel: Twin Readers' Advisory Pleasures, 50(2):122-125

Trott, Barry. Helen E. Haines: A Life with Books, 50(1):14-17

Williamson, Tara Bannon. Materials Matchmaking: Articulating Whole Library Advisory, 50(3):230-234

The Reading List 2011, 50(4):335336

A Reference Librarian in Special Collections: Making the Most of a Learning Opportunity, 50(4):319-321

REFERENCE SERVICES. See also BUSINESS REFERENCE SOURCES; VIRTUAL REFERENCE SERVICES Agosto, Denise E.,, Lily Rozaklis, Craig MacDonald, and Eileen G. Abels. A Model of the Reference and Information Service Process: An Educators' Perspective, 50(3):235-244

Bejune, Matthew M., and Sara E. Morris. The Development of the Virtual Notebook, a Wiki-Based Ready Reference Technology, 50(1):27-34

Wolfe, Judith A., Ted Naylor, and Jeanetta Drueke. The Role of the Academic Reference Librarian 
in the Learning Commons, 50(2):108-113

REFERENCE SOURCES. See also WEB REFERENCE SOURCES

East, John W. "The Rolls Royce of the Library Reference Collection": The Subject Encyclopedia in the Age of Wikipedia, 50(2):162-169

Resource Description and Access (RDA): An Introduction for Reference Librarians, 50(3):216-222

The Role of the Academic Reference Librarian in the Learning Commons, 50(2):108-113

"The Rolls Royce of the Library Reference Collection": The Subject Encyclopedia in the Age of Wikipedia, 50(2):162-169

Rozaklis, Lily. See Agosto, Denise E. RUSA

BRASS Business Reference Sources Committee. Outstanding Business Reference Sources, 50(2):126-130

BRASS Program Planning Committee. Clean, Green, and Not So Mean: Can Business Save the World?, 50(2):135-140

GUIDELINES (See GUIDELINES)

Notable Books Council. Notable Books, 50(4):330-332

RUSA CODES Reading List Council. The Reading List 2011 , 50(4):335-336

RUSA CODES Reference Sources Committee. Outstanding Reference Sources, 50(4):333334

RUSA History Section Historical Materials Committee. Best Historical Materials, 50(1):2526

RUSA Machine-Assisted Reference Section. Best Free Web Reference Websites, 50(1):1924

Ryan, Marianne, ed. Management (column), 50(2):119$121,50(4): 322-324$

\section{S}

Sabolcsi-Boros, Susanna. See

Radford, Marie L.

Saricks, Joyce. See Baker, Jen Sasaki, Jacqueline. See Baker, Jen
A Selection of Core Resources for Readers' Advisory Service, 50(1):6,8-12

Shen, Lisa. See Cassidy, Erin Dorris

Sobel Karen, and Kenneth Wolf

Updating Your Tool Belt:

Redesigning Assessments of Learning in the Library, 50(3):245-258

SOCIAL MARKETING

O'Connor, Lisa, and Kacy Lundstrom. The Impact of Social Marketing Strategies on the Information Seeking Behaviors of College Students, 50(4):351-365

SOCIAL NETWORKING

Cassidy, Erin Dorris, James Britsch, Glenda Griffin, Tyler Manolovitz, Lisa Shen, and Linda Turney. Higher Education and Emerging Technologies: Student Usage, Preferences, and Lessons for Library Services, 50(4):380-391

SOCIAL SOFTWARE

Kooy, Brian K., and Sarah K. Steiner. Protection, Not Barriers: Using Social Software Policies to Guide and Safeguard Students and Employees, 50(1):59-71

SPACE (LIBRARIES)

Elmborg, James K. Libraries as the Spaces Between Us: Recognizing and Valuing the Third Space, 50(4):338-350

Spencer, Brett. See Taylor, Stephanie D. Steiner, Sarah K. See Kooy, Brian K. Stover, Kaite Mediatore. See Baker, Jen Stover, Mark

From Reference Librarian to Interim Dean: A Journey of Comparisons and Contrasts, 50(4):322-324

Strothmann, Molly, and Karen Antell The Live-In Librarian: Developing Library Outreach to University Residence Halls, 50(1):48-58

\section{$\mathbf{T}$}

Taylor, Stephanie D., R. Alexander

Perry, Jessica L. Barton, and Brett Spencer

A Follow-Up Study of the Factors Shaping the Career Choices of Library School Students at the University of Alabama, 50(1):35-47

Trott, Barry. See also Baker, Jen

Trott, Barry, ed.

Note re Tara Williamson's column, 50(4):329

From the President of RUSA (column), 50(4):314

Readers' Advisory (column), 50(1):14-17, 50(2):122-125, 50(3):230-234, 50(4):325-329

Turney, Linda. See Cassidy, Erin Dorris

\section{U}

Updating Your Tool Belt:

Redesigning Assessments of Learning in the Library, 50(3):245-258

\section{VIRTUAL NOTEBOOK}

Bejune, Matthew M., and Sara E. Morris. The Development of the Virtual Notebook, a Wiki-Based Ready Reference Technology, 50(1):27-34

VIRTUAL REFERENCE SERVICES

Bosančić, Boris. A Blueprint for Building Online Reference Knowledge Bases, 50(2):152-161

Dixon, Lydia, Cheri Duncan, Jody Condit Fagan, Meris Mandernach, and Stefanie E.Warlick. Finding Articles and Journals via Google Scholar, Journal Portals, and Link Resolvers: Usability Study Results, 50(2):170-181

Duncan, Vicki, and Angie Gerrard. All Together Now! Integrating Virtual Reference in the Academic Library, 50(3):280292

Guidelines for Implementing and Maintaining Virtual Reference Services, 50(1):92-96

Pomerantz, Jeffrey. Identifying Reusable Resources in Digital Reference Responses, 50(4):366-378

Radford, Marie L., Lynn Silipigni Connaway, Patrick A. Confer, Susanna Sabolcsi-Boros, and Hannah Kwon. "Are We Getting Warmer?" Query Clarification 


\section{INDEX TO VOLUME 50}

in Live Chat Virtual Reference, 50(3):259-279

Voelker, Tammy J. Eschedor, ed. Reference Books, 50(1):72-87, 50(2):183-191, 50(3):294-305, 50(4):393-404

\section{W}

Warlick, Stefanie E. See Dixon, Lydia

WEB REFERENCE SOURCES

Best Free Web Reference Websites, 50(1):19-24

Best of the Best Business Websites, 50(2):132-134

Wells, Kimberly. See Baker, Jen

Who Says There's a Problem? A New

Way to Approach the Issue of

"Problem Patrons," 50(2):141-151

WIKIPEDIA

East, John W. "The Rolls Royce of the Library Reference Collection": The Subject Encyclopedia in the Age of Wikipedia, 50(2):162-169

Williamson, Tara Bannon

Materials Matchmaking: Articularing Whole Library Advisory, 50(3):230-234

Wolf, Kenneth. See Sobel, Karen

Wolfe, Judith A., Ted Naylor, and

Jeanetta Drueke

The Role of the Academic Reference Librarian in the Learning Commons, 50(2):108-113

Wright, David. See Baker, Jen Wyatt, Neal, ed.

The Alert Collector (column), 50(1):6, 8-12, 50(3):210-215, 50(4):315-318

\section{Z}

Zabel, Diane, ed.

From the Editor (column), 50(1):4, 50(4):312-313

For Your Enrichment (column), 50(2):108-113, 50(3):216-222, 50(4):319-321

\section{Sources}

\section{A}

Active Learning Techniques for Librarians: Practical Examples, 50(4):404

America in World History, 50(1):73
The American Beauty Industry

Encyclopedia, 50(2):183

American Women in Science Since 1900, 50(4):393

America's Natural Places, 50(1):7374

Asian American History and Culture: An Encyclopedia, 50(1):74

Assessing Service Quality: Satisfying the Expectations of Library Customers, 50(2):191-192

\section{B}

Boomers and Beyond: Reconsidering the Role of Libraries, 50(4):404-405

Boy Culture: An Encyclopedia, 50(4):393-394

Building Bridges: Connecting Faculty, Students, and the College Library, 50(2):192

Children's Services: Partnerships for Success, 50(3):305

The Concise Encyclopedia of the Great Recession, 2007-2010, 50(3):294

The Concise Encyclopedia of World War II, 50(2):183-184

Consumer Americas 2011, 50(4):394

Crime and Punishment Around the World, 50(4):394-395

Critical Library Instruction: Theories and Methods, 50(3):305-306

Cultural Encyclopedia of Vegetarianism, 50(4):395-396

Culture Wars: An Encyclopedia of Issues, Viewpoints, and Violence, 50(1):74

Customer Care: A Training Manual for Library Staff, 50(2):192-193

\section{D}

Designing Space for Children and Teens in Libraries and Public Places, 50(4):405

Developing an Outstanding Core Collection: A Guide for Libraries, 50(3):306

Developing Library Leaders: A How to do-it Manual for Coaching,
Team Building, and Mentoring Library Staff, 50(4):405

\section{E}

The Early Republic and Antebellum America: An Encyclopedia of Social, Political, Cultural, and Economic History, 50(3):294-295

Effective Blogging for Libraries, 50(2):193

Encyclopedia of Aerospace Engineering, 50(4):396-397

Encyclopedia of Africa, 50(1):74-75

Encyclopedia of African-American Actresses in Film and Television, 50(1):75-76

Encyclopedia of African-American Education, 50(1):76

Encyclopedia of African-American History, 50(1):76-77

Encyclopedia of American Immigration, 50(2):184

Encyclopedia of Case Study Research, 50(1):77

The Encyclopedia of Christian Literature, 50(2):184-185

Encyclopedia of Comic Books and Graphic Novels, 50(2):185

Encyclopedia of Criminological Theory, 50(4):397

Encyclopedia of Depression, 50(2):185-186

Encyclopedia of Educational Reform and Dissent, 50(3):295

Encyclopedia of Emotion, 50(3):295-296

Encyclopedia of Global Resources, 50(2):186-187

Encyclopedia of Global Warming, 50(1):77-78

Encyclopedia of Group Processes and Intergroup Relations, 50(2):187

Encyclopedia of Identity, 50(3):296-297

Encyclopedia of Journalism, 50(2):187-188

Encyclopedia of Law and Higher Education, 50(2):188-189

Encyclopedia of Modern China, 50(1):78-79

Encyclopedia of Motherhood, 50(2):189

Encyclopedia of Nanoscience and Society, 50(3):297-298 
Encyclopedia of Organic, Sustainable, and Local Food, 50(1):79

Encyclopedia of Perception, 50(1):79-80

Encyclopedia of Political Theory, 50(4):397-398

Encyclopedia of Religion in America, 50(4):398-399

Encyclopedia of Research Design, 50(4):399

Encyclopedia of Science and Technology Communication, 50(3):298

Encyclopedia of Sustainability, 50(1):80-81

Encyclopedia of the Vampire: The Living Dead in Myth, Legend, and Popular Culture, 50(4):399-400

Encyclopedia of Urban Studies, 50(1):81

Encyclopedia of U.S. Political History, 50(1):81-82

Encyclopedia of Vampire Mythology, 50(4):399-400

Encyclopedia of Victimology and Crime Prevention, 50(4):400

Environmental Issues, Global Perspectives, 50(3):298-299

Every Day of the Civil War: A Chronological Encyclopedia, 50(3):299

\section{$\mathbf{F}$}

The Fertilizer Encyclopedia, 50(1):82-83

The Forties in America, 50(3): 299-300

\section{G}

A Global Chronology of Conflict: From the Ancient World to the Modern Middle East, 50(1):83

Graphic Novels and Comics in Libraries and Archives: Essays on Readers, Research, History and Cataloging, 50(3):306-307

\section{H}

Healthy Foods: Fact Versus Fiction, 50(3):300

Hip-Hop in America: A Regional Guide, 50(4):400-401

Humanism and Libraries: An Essay on the Philosophy of Librarianship, 50(1):87
Icons of Mystery and Crime Detection: From Sleuths to Superheroes, 50(3):300-301

Intellectual Freedom Manual, 50(4):405-406

The International Encyclopedia of Gambling, 50(1):83-84

\section{$\mathbf{L}$}

Latino History and Culture: An Encyclopedia, 50(1):84

Librarians as Community Partners: An Outreach Handbook, 50(2):193-194

The Librarian's Guide to Graphic Novels for Adults, 50(1):87-88

Literary Research Guide, 50(3):301

\section{M}

Marketing Today's Academic Library: A Bold Approach to Communicating with Students, 50(1):88

Microblogging and Lifestreaming in Libraries, 50(2):194

Milestone Documents in AfricanAmerican History, 50(3):301-302

Milestone Documents in World History: Exploring the Primary Sources That Shaped the World, 50(2):189-190

Mormonism: A Historical Encyclopedia, 50(4):401

Muslim World: Illustrated Dictionary of the Muslim World, 50(4):401-402

Muslim World: Islamic Beliefs, Practices, and Cultures, 50(4):401-402

Muslim World: Modern Muslim Societies, 50(4):401-402

\section{N}

Native Americans Today: A Biographical Dictionary, 50(3):302-303

The Oxford International Encyclopedia of Peace, 50(2):190

Pirates of the Americas, 50(1): 84-85
Productivity for Librarians: How to Get More Done in Less Time, 50(2):194

Protecting Intellectual Freedom in Your School Library: Scenarios from the Front Line, 50(1):88-89

Public Libraries Going Green, 50(2):195

Public Library Services for the Poor: Doing All We Can, 50(3):307

\section{$\mathbf{R}$}

The Readers' Advisory Handbook, 50(3):307

Reference Renaissance: Current and Future Trends, 50(1):89

Retail Trade International, 50(4):394

Risky Business: Taking and Managing Risks in Library Services for Teens, 50(4): 406-407

\section{S}

Salem Health: Genetics and Inherited Conditions, 50(2):190191

Scientific Exploration and Expeditions: From the Age of Discovery to the Twenty-First Century, 50(4):402

Searching 2.0, 50(1):89-90

Seas and Waterways of the World: An Encyclopedia of History, Uses, and Issues, 50(1):85

September 11 in Popular Culture: A Guide, 50(3):303

Serving Boys through Reader's Advisory, 50(1):90

A Social Networking Primer for Librarians, 50(2):195

The Social Transcript: Uncovering Library Philosophy, 50(1):90-91

Space Exploration and Humanity: A Historical Encyclopedia, 50(3):303-304

Spaceflight: A Historical Encyclopedia, 50(1):85-86

Stop Plagiarism: A Guide to Understanding and Prevention, 50(4):406-407

Succession Planning in the Library, 50(3):308 


\section{INDEX TO VOLUME 50}

\section{T}

Teaching Information Literacy: 50 Standards-Based Exercises for College Students, 50(4):407

Technology Training in Libraries, 50(2):195-196

Toys and American Culture: An Encyclopedia, 50(1):86-87

Trials of the Century: An Encyclopedia of Popular Culture and the Law, 50(4):402-403

Truman Capote Encyclopedia, 50(2):191
Twenty-First-Century Kids, TwentyFirst-Century Librarians, 50(3):308

\section{U}

Urban Teens in the Library, 50(1):91

\section{W}

Web-Based Instruction: A Guide for Libraries, 50(4):407-408
World Consumer Income and Expenditure Patterns, 2011, 50(3):304

World Directory of Business Information Services, 50(3):304305

World War II and the Postwar Years in America: A Historical and Cultural Encyclopedia, 50(4):403-404 